EISSN: 2706 -7947 ISSN: 2077- 4613

DOI: 10.36632/mejas/2021.11.1.2

Journal homepage: www.curresweb.com

Pages: 10-17

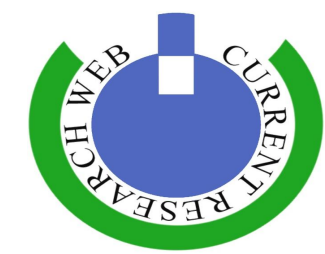

\title{
Potential Probiotic Activity of Lactic Acid Bacteria Isolated from Vended Dairy Products
}

\section{Mohamed Abdel baser ${ }^{1}$, Samy Mohamed Abdelhamid ${ }^{2}$, Ahmed Ali Attia Radwan ${ }^{1}$ and Hussien Hossney El-Shikh ${ }^{1}$}

${ }^{1}$ Department of Botany and Microbiology, Faculty of Science, Al-Azhar University, Nasr City, Cairo, 11884, Egypt.

${ }^{2}$ Dairy Department, Food Industries and Nutrition Division, National Research Center, Cairo, Egypt.

Received: 10 November 2020 Accepted: 24 December 2020 Published: 10 January 2021

\begin{abstract}
Nowadays, there is an increasing regard in the production of functional foods, predominantly probiotic foods. Lactic acid bacteria (LAB), especially strains of Lactococcus spp. and Lactobacillus spp., are important bacteria in field of food microbiology and human nutrition. The traditional, fermented dairy foods as a rich source of wild LAB can insert new Lactococcus spp. And Lactobacillus spp. strains having probiotic properties into some food products. The aim of this study was isolate and identify LAB in traditional vended dairy products and to determine some of their probiotic properties. Out of thirty samples of street vender different dairy products, three samples including homemade yogurt, raw milk and white cheese were found to contain Lactococcus spp. and lactobacillus spp., which were identified using biochemical and molecular testing. Potential probiotic properties, including acid and bile tolerant, antimicrobial activity, and antibiotic susceptibility were assayed for the. isolates The Lactococcus spp. and lactobacillus spp. isolates showed tolerance to $\mathrm{pH} 2$ and $0.3 \%$ bile salt after $3 \mathrm{~h}$ of incubation and also showed antimicrobial activity against coded test organisms represented by Gram negative bacteria; Escherichia coli ATCC 8739, Aeromonas salmonicida ATCC 9033 and Gram positive bacteria represented by Staphylococcus aureus ATCC 29213, Enterococcus faecalis NCTC 10413. Furthermore, they have been assayed for their antibiotic susceptibility. In conclusion, these strains of Lactococcus spp. and lactobacillus spp. isolated from vended dairy products showed alike some of probiotic activity.
\end{abstract}

Keywords: Probiotic potential activity, lactic acid bacteria, dairy products.

\section{Introduction}

Fermented foods and dairy products have emerged as not only the source of nutrition but also as functional and probiotic foods, which provide protection against many food-borne diseases (Bell et al., 2018). Assorted in vitro studies signalized that the growth of food-borne pathogenic microbes was inhibited by probiotic lactic acid bacteria (Khaneghah et al., 2020). The exhaustion of a large number of probiotic live microorganisms together with a food mainly elevates the health and immunity of the consumers (Terpou et al., 2019).

Probiotic bacteria are defined as live microbial feed supplements that beneficially affects the host by improving its intestinal microbial balance live (Kolacek et al., 2017; Shokryazdan et al., 2017). The various genera of bacteria most generally used in probiotic formulations are Lactobacillus, Bifidobacterium, Enterococcus and Streptococcus, and some fungal strains most of them considered as gut commensals (Fijan et al., 2018).

There is growing interest on probiotics in both of basic and clinical sciences (Rondanelli et al., 2017). Some characteristics of bacterial strains are distinguished to be a potential probiotic strain such

Corresponding Author: Mohamed Abdel baser, Department of Botany and Microbiology, Faculty of Science, Al-Azhar University, Nasr City, Cairo, 11884, Egypt 
as the ability to survive and colonization in the gastrointestinal environment, production of antibacterial substance resistance to gastric, bile salt and antibiotic resistance activities (Vinderola et al., 2017).

Lactic acid bacteria (LAB) are a varied group of microorganisms consisting of Gram-positive, aero-tolerant, acid-tolerant, usually non-spore forming. LAB play an important role in the fermentation process for different foods by inhibiting spoilage/pathogenic bacteria, producing excellent flavor, aroma, anti-bacterial substance and giving texture (Mulaw et al., 2019). LAB were isolated from various sources such as fermented foods, milk products, animal intestines or freshwater fishes, soil samples, sugar cane plants, and poultry farms (Mulaw et al., 2019). The most popular species of probiotic LAB include distinct Lactobacillus spp. and genus Bifidobacteria (Vale et al., 2016; Xiao et al., 2020). In particularly, Lactobacilli produce a broad spectrum of proteins and peptides called antibiotics, with variable antimicrobial activity and low or absent phenomena of antibiotic resistance. (Santacroce et al., 2019).

This study aimed to isolate and identify LAB strains from different dairy products, determine their probiotic potential activity via acid and bile tolerant and the ability of these organisms to inhibit the growth of coded test pathogenic some food borne bacteria represented by some Gram negative \& positive bacteria and additionally assay their susceptibility against different antibiotics.

\section{Materials and Methods}

\subsection{Sample Collection.}

Thirty samples including yogurt, raw milk and cheese were purchased from several rural areas in Al Mahala city, Egypt. Samples after collection were immediately placed in an ice box (250 g each) and each sample was suspended and homogenized into $10 \mathrm{~mL}$ sodium citrate $(2 \% \mathrm{w} / \mathrm{v})$. Afterward, 0.1 $\mathrm{mL}$ from each dilution was then sub-cultured aseptically into MRS (deMan Rogosa and Sharpe) agar using pour plate technique (Guessas and Kihal, 2004). All plates were then incubated at $37^{\circ} \mathrm{C}$ for $24-48$ $\mathrm{h}$ in anaerobic condition to provide an optimal environmental for growing of Lactobacillus spp.

Only Gram positive and rod shape isolates were then purified by streaking plates of MRS medium. After several subcultures, primarily each suspected single colony of LAB was isolated via observing their colony morphology and Gram staining. The culture was kept in MRS agar slant and stored at $4{ }^{\circ} \mathrm{C}$ for more biochemical molecular identification and long term storage (Hawaz, 2014).

While pathogenic bacteria, were delivered from Diary microbiology laboratory, National Research Center, Cairo, Egypt. The bacteria was coded and represented by Gram negative bacteria, as Escherichia coli ATCC 8739, Aeromonas salmonicida ATCC 9033 and Gram positive bacteria as Staphylococcus aureus ATCC 29213, Enterococcus faecalis NCTC 10413. All strains were grown on nutrient agar media and incubated at $37^{\circ} \mathrm{C}$ for $24 \mathrm{~h}$, and preserved in slant tubes at $4^{\circ} \mathrm{C}$ for further studies.

\subsection{Biochemical identification of the isolates}

\subsubsection{Biochemical identification}

Identification of the most potent LAB bacterial isolates No. M_5, M_11 and M_22 were performed basically according to many different biochemicals international Key's using Bergey's Manual of Systematic Bacteriology (2009), through the well known physiological and biochemical properties of the most potent $\mathrm{LAB}$ bacterial, then the well identified isolates were confirmed by the molecular assay using $16 \mathrm{~S}$ rRNA technique.

\subsubsection{Molecular identification}

Total DNA was extracted was extracted according to modified method (Miller et al., 1999). Briefly, individual colonies from an agar plate were picked up using a sterile toothpick or inoculating loop and re-suspended in $50 \mu \mathrm{l}$ sterile deionized water. The cell suspension was placed in a water bath at $97^{\circ} \mathrm{C}$ and "cooked" for 10 minutes, and the cell lysate was obtained via centrifugation $(15,000 \times \mathrm{g}$, 10 minutes), and removing the supernatant containing the DNA with an aliquot $(1 \mu \mathrm{l})$ and PCR reagent mix. Following this, 16S rRNA gene was amplified in polymerase chain reaction (PCR) using the genomic DNA as template and bacterial universal primers, $27 \mathrm{f}$ (5-GAGTTTGATCACTGGCTCAG3 ) and 1492r (5 TACGGCTACCTTGTTACGACTT-3) (Lane, 1991) to amplify an approximately 1.5 $\mathrm{Kb}$ of $16 \mathrm{~S}$ rRNA gene. The PCR mixture $(50 \mu \mathrm{L})$ contained $1 \times$ PCR buffer, $0.5 \mathrm{mM} \mathrm{MgCl}, 2.5 \mathrm{U}$ Taq 
DNA polymerase (QIAGEN), $0.25 \mathrm{mM}$ dNTP, $0.5 \mu \mathrm{M}$ of each primer, and $1 \mu 1$ of extracted bacterial genomic DNA. The PCR was performed in a DNA Engine Thermal Cycler (PTC-200, BIO-RAD, USA) with a hot starting performance at $94^{\circ} \mathrm{C}$ for $3 \mathrm{~min}$, followed by 30 cycles of $94^{\circ} \mathrm{C}$ for $0.5 \mathrm{~min}, 55^{\circ} \mathrm{C}$ for $0.5 \mathrm{~min}$, and $72^{\circ} \mathrm{C}$ for $1 \mathrm{~min}$, followed by a final extension performance at $72^{\circ} \mathrm{C}$ for $10 \mathrm{~min}$. The PCR products were sequenced at the Genome Quebec Innovation Center Facility (Montreal, Canada) with the two primers. The 16S rRNA sequence was compared against the GenBank database using the NCBI BLAST program. Sequences were then compared with $16 \mathrm{~S}$ rRNA sequences in the GenBank database using BLASTN. Multiple sequence alignment was done using ClustalX 1.8 software package (http://wwwigbmc.u-strasbg.fr/BioInfo/clustalx).

\subsection{Screening assays for the most probiotic potent $L A B$.}

Plates of MRS agar medium with purified LAB isolates were incubated for $37^{\circ} \mathrm{C} / 48$ hours. Four tests were used to select the most probiotic potent LAB isolates.

\subsubsection{Acid and Bile tolerance.}

The isolates were grown $\sim 10^{9} \mathrm{cfu} / \mathrm{mL}$ in MRS broth at $37^{\circ} \mathrm{C} / 48 \mathrm{~h}$ and centrifuged for $15 \mathrm{~min}$ at $6000 \times \mathrm{g}$. The cell pellets were suspended in Phosphate buffer saline (PBS, $\mathrm{pH} 2.0)$ and bile $(0.3 \%$ Oxgall, Sigma), then incubated at $37^{\circ} \mathrm{C}$ for $3 \mathrm{~h}$. After centrifugation, cells were suspended in $10 \mathrm{~mL}$ MRS broth and incubated for $24 \mathrm{~h}$ at $37^{\circ} \mathrm{C}$. One Millimeter from each solution was serially diluted and a given amount of each dilution $(100 \mu \mathrm{L})$ was spread onto MRS agar plates and incubated in the anaerobic condition at $37^{\circ} \mathrm{C}$ for $72 \mathrm{~h}$. The resistant rate was calculated by comparing treated/untreated cell survival. The survival rate was calculated using the following equation:

Survival rate $\%=(\log \mathrm{cfu} N 1 / \log \mathrm{cfu} N 0) \times 100$

$\mathrm{N} 1=$ total viable counts of bacterial isolates in the MRS agar after being treated with extra bile salts or in low acidic conditions. While $\mathrm{N} 0=$ total viable counts of isolates before incubation in harsh conditions (Haghshenas et al., 2016). The selection of LAB was done due to high ratio of acid and bile tolerance.

\subsubsection{Antimicrobial activity assay.}

The antimicrobial activity of the isolates was assayed against coded test organisms represented by Gram negative bacteria as, Escherichia coli ATCC 8739, Aeromonas salmonicida ATCC 9033 and Gram positive bacteria represented by Staphylococcus aureus ATCC 29213, Enterococcus faecalis NCTC 10413. The LAB isolated strains were cultured in MRS broth overnight at $37^{\circ} \mathrm{C}$ and cell free supernatants were prepared by centrifuging culture broth at $8000 \times \mathrm{g}$ for $15 \mathrm{~min}$. The supernatants were adjusted to $\mathrm{pH} 6.5$ and filtered through $0.22 \mu \mathrm{m}$ membrane filter and then $6 \mathrm{~mm}$ diameter of sterile filter paper disks impregnated with a defined concentration $(100 \mu l)$ from each strains of LAB. Using a disk dispenser or sterile forceps, the disks were placed in even array on the plate, at well-spaced intervals from each other. When the disks are in firm contact with the agar, the supernatants were diffuse into the surrounding medium and come in contact with the multiplying organisms. The plates were incubated at $35^{\circ} \mathrm{C}$ for 18 to 24 hours. After incubation, the plates were examined for the presence of zones of inhibition of bacterial growth (clear zone) and measuring $\mathrm{mm}$ diameter as inhibition zone around the filter paper disks (Demirbaş et al., 2017).

\subsection{Antibiotic susceptibility assay.}

The antibiotic susceptibility assay was determined using the disk diffusion method (Ozteber and Başbülbül, 2017). The antibiotic disks including chloramphenicol $(30 \mu \mathrm{g})$, vancomycin $(30 \mu \mathrm{g})$, tetracycline $(30 \mu \mathrm{g})$, erythromycin $(15 \mu \mathrm{g})$, ampicillin $(10 \mu \mathrm{g})$, sulfamethoxazole $(25 \mu \mathrm{g})$, streptomycin $(25 \mu \mathrm{g})$ and penicillin $(10 \mu \mathrm{g})$ were purchased from Sigma Co. (Cairo, Egypt). The LAB strains were cultured on Mueller-Hinton agar plates then the antibiotic disks were manually placed on plates by using the sterile forceps previously inoculated with LAB and then plate were incubated at $37{ }^{\circ} \mathrm{C}$ for 24 h. After incubation, the inhibition zone was measured and susceptibility was expressed in terms $\mathrm{S}$ : Sensitive (zone diameter $\geq 17.5 \mathrm{~mm}$ ); MS: Moderately sensitive (zone diameter 12.5-17.4 mm); R: resistant (zone diameter $\leq 12.4 \mathrm{~mm}$ ) (Haghshenas et al., 2016). 


\section{Statistical analysis}

The means of three replications and standard error ( $\mathrm{S} . \mathrm{Er} \pm$ ) were calculated for all the results obtained, and the data were subjected to analysis of variance means by spss.18.0 program.

\section{Results and Discussion}

\subsection{Selection and identification of LAB and acid \&bile salt tolerance assay.}

Data represented in table (2) showed some morphological, physiological and biochemical properties of the bacterial isolates according to Bergey's Manual of Systematic Bacteriology (2009). It could be stated that M_5, M_11 and M_22 were related to Lactococcus lactis, Lactobacillus rhamnosus and Lactobacillus plantarum, respectively.

The LAB isolates of Lactococcus spp. and lactobacillus spp. (M_5, M_11 and M_22) as represented in Table (1) were identified using biochemical then, molecular identification assay. LAB strains were selected for probiotic activity according to its ability to tolerant acid and bile salt (Faghfoori et al., 2017). Bile salt plays a fundamental role in specific and non-specific defense mechanisms in the gut and the magnitude of its inhibitory effects is determined primarily by its concentrations (Prete et al., 2020). Bile salt tolerance is one of the prerequisite properties for probiotic bacteria to survive in the small intestine and to be functionally effective. L. brevis DT24 showed higher bile salt tolerance compared to other isolates and slightly lower than L. acidophilus NCDC 15 (Fijan, 2016). Results reveal that all Lactococcus spp. and lactobacillus spp. isolates tolerate $0.3 \%$ bile salts with count of $8.3-8.6$ $\log \mathrm{CFU} / \mathrm{ml}$.

The molecular identification based on 16S rRNA gene amplification showed that the bacterial strain (M_5) had 94\% similarity to Lactococcus lactis subsp. lactis. While bacterial strains of M_11 and $M_{2} 2$ had $100 \%$ and $98 \%$ similarity to Lactobacillus rhamnosus Tistr 541 and Lactobacillus plantarum Dsaz 0174, respectively. Jarocki et al., (2018) used 16S rRNA gene sequence for identification of Lactobacillus rhamnosus, while Liu et al., (2012) used 16S rRNA gene sequence for identification of Lactococcus lactis subsp. lactis (in 16.7\% out of 132 strains), Lactobacillus plantarum and Lactobacillus casei (11.0\% out of 106 strains).

Table 1: Acid and Bile tolerance tests for Lactococcus spp. and Lactobacillus spp

\begin{tabular}{lllll}
\hline No. & Code & \multicolumn{1}{c}{ Molecular identification } & $\begin{array}{c}\text { Acidity tolerance, } \\
\mathbf{p H ~ 2 . 0}(\mathbf{l o g} \\
\mathbf{c f u} / \mathbf{m L})\end{array}$ & $\begin{array}{c}\text { Bile salt tolerance, } \\
\mathbf{0 . 3 \%} \text { bile salt (log } \\
\mathbf{c f u} / \mathbf{m L})\end{array}$ \\
\hline $\mathbf{1}$ & M_5 & Lactococcus lactis & 8.31 & 8.43 \\
$\mathbf{2}$ & M_11 & Lactobacillus rhamnosus Tistr 541 & 8.58 & 8.35 \\
$\mathbf{3}$ & M_22 & Lactobacillus plantarum Dsaz 0174 & 8.68 & 8.67 \\
\hline
\end{tabular}

Table 2: Morphological, physiological and biochemical properties of the most potent LAB bacterial isolates

\begin{tabular}{|c|c|c|c|c|c|c|}
\hline Organisms & Tests & Cell shape & $\begin{array}{l}\text { Gram's stain } \\
\text { reaction }\end{array}$ & $\begin{array}{l}\text { Endospore } \\
\text { produced }\end{array}$ & $\begin{array}{c}\text { Gelatin } \\
\text { hydrolysis }\end{array}$ & $\begin{array}{c}\text { Nitrate } \\
\text { reduction }\end{array}$ \\
\hline M_5 & & Cocci & + & - & - & - \\
\hline M_11 & & Rod & + & - & - & - \\
\hline M 22 & & Rod & + & . & . & - \\
\hline Organisms & Tests & $\begin{array}{l}\text { Urease } \\
\text { production }\end{array}$ & $\begin{array}{l}\text { Acetate } \\
\text { Utilization }\end{array}$ & $\begin{array}{c}\text { Fermentation of } \\
\text { Fructose }\end{array}$ & $\begin{array}{c}\text { Fermentation of } \\
\text { Lactose }\end{array}$ & $\begin{array}{c}\text { Lipid } \\
\text { hydrolysis }\end{array}$ \\
\hline M_5 & & + & - & + & + & + \\
\hline M_11 & & + & - & + & + & + \\
\hline $\mathrm{M}_{-2}^{-} 2$ & & + & - & + & + & + \\
\hline
\end{tabular}

Table 2: Cont.

\begin{tabular}{cccccc}
\hline Tests & Methyl red & $\begin{array}{c}\text { Citrate } \\
\text { utilization }\end{array}$ & $\begin{array}{c}\text { Indole } \\
\text { production }\end{array}$ & $\begin{array}{c}\mathrm{H}_{2} \mathrm{~S} \\
\text { production }\end{array}$ & $\begin{array}{c}\text { Voges } \\
\text { Proskauer }\end{array}$ \\
\hline M_5 & + & - & - & - & - \\
M_11 & - & - & - & - & - \\
M_22 & + & - & - & - & + \\
\hline
\end{tabular}


Table 2: Cont.

\begin{tabular}{cccccc}
\hline Organisms & $\begin{array}{c}\text { Tests } \\
\text { of Sucrose }\end{array}$ & $\begin{array}{c}\text { Fermentation } \\
\text { of Glucose }\end{array}$ & $\begin{array}{c}\text { Peroxidase } \\
\text { production }\end{array}$ & $\begin{array}{c}\text { Catalase } \\
\text { production }\end{array}$ & $\begin{array}{c}\text { Oxidase } \\
\text { production }\end{array}$ \\
\hline M_5 & + & + & - & - & - \\
M_11 & + & + & - & - & - \\
M_22 & + & + & - & - & - \\
\hline
\end{tabular}

+ , positive result; -, negative result.

M_5, M_11 and M_22 were biochemically and genetically identified as Lactococcus lactis subsp. lactis, Lactobacillus rhamnosus and Lactobacillus plantarum, respectively.

\subsection{Antimicrobial activity}

The antimicrobial activity of lactic acid bacteria (Lactococcus lactis; L. rhamnosus and L. plantarum) was assayed against test coded food borne pathogenic bacteria represented by Gram negative bacteria as Escherichia coli ATCC 8739, Aeromonas salmonicida ATCC 9033 and Gram positive bacteria represented by Staphylococcus aureus ATCC 29213, Enterococcus faecalis NCTC 10413, using paper disk method on Mueller Hinton agar plates which expressed as diameter of inhibition zone in (mm). Results in Table (3) and Figure (1) showed that, the antagonistic effect of Lactococcus lactis against the coded test pathogenic bacteria of E coli; Staphylococcus aureus; Aeromonas salmonicida and Enterococcus faecalis was recorded at 10.66, 11.66, 11.33 and 12.6mm, respectively. While, in case of $L$. rhamnosus antimicrobial against the coded test organisms showed the inhibition zones around disks as recorded 9.4, 9, 8.7 and $10.1 \mathrm{~mm}$, respectively. Additionally, $L$. plantarum recorded 10.3, 8.33,10 and $8.6 \mathrm{~mm}$ against the coded test organisms. It is well known that $\mathrm{LAB}$ are among the most powerful bacteria in regard to antimicrobial potential as produce several antimicrobials and also compete with other bacterial species by rapidly depleting the nutrients and acidifying their environment. In besides, some LAB also produces potential antibiotic compounds as reutericyclin, reuterin and nisin via secondary metabolic pathways (Toplaghaltsyan et al., 2017).

According to the current results, Lactococcus lactis was select as the best LAB had high antibacterial effect against test coded organisms represented by Gram negative bacteria, Escherichia coli ATCC 8739, Aeromonas salmonicida ATCC 9033 and Gram positive bacteria represented by Staphylococcus aureus ATCC 29213, Enterococcus faecalis NCTC 10413, followed by L. plantarum and L. rhamnosus, respectively, as illustrated in Plate (1)

Table 3: Antimicrobial activity of LAB strains against coded test foodborne pathogenic bacteria.

\begin{tabular}{lcccc}
\hline $\begin{array}{l}\text { Isolates } \\
\text { name }\end{array}$ & $\begin{array}{c}\text { E. coli } \\
\text { mm Inh. } *\end{array}$ & $\begin{array}{c}\text { Staphylococcus aureus } \\
\text { mm Inh. * }\end{array}$ & $\begin{array}{c}\text { Aeromonas } \\
\text { salmonicida mm } \\
\text { Inh. * }\end{array}$ & $\begin{array}{c}\text { Enterococcus } \\
\text { faecalis } \\
\text { mm Inh. * }\end{array}$ \\
\hline Lactococcus lactis & $10.6 \pm 0.01 \mathrm{a}$ & $11.66 \pm 0.1 \mathrm{a}$ & $11.33 \pm 0.02 \mathrm{a}$ & $12.6 \pm 0.2 \mathrm{a}$ \\
L. rhamnosus & $9.42 \pm 0.03 \mathrm{~b}$ & $9.0 \pm 0.03 \mathrm{~b}$ & $8.71 \pm 0.05 \mathrm{ab}$ & $10.1 \pm 0.01 \mathrm{~b}$ \\
L. plantarum & $10.3 \pm 0.01 \mathrm{a}$ & $8.33 \pm 0.04 \mathrm{~b}$ & $10.0 \pm 0.01 \mathrm{~b}$ & $8.6 \pm 0.03 \mathrm{c}$ \\
\hline
\end{tabular}

Mean \pm SE $(\mathrm{n}=3)$. * mm Inhibition zones

\section{$\square$ Lactococcus lactis $\square$ L. rhamnosus $\square$ L. plantarum}

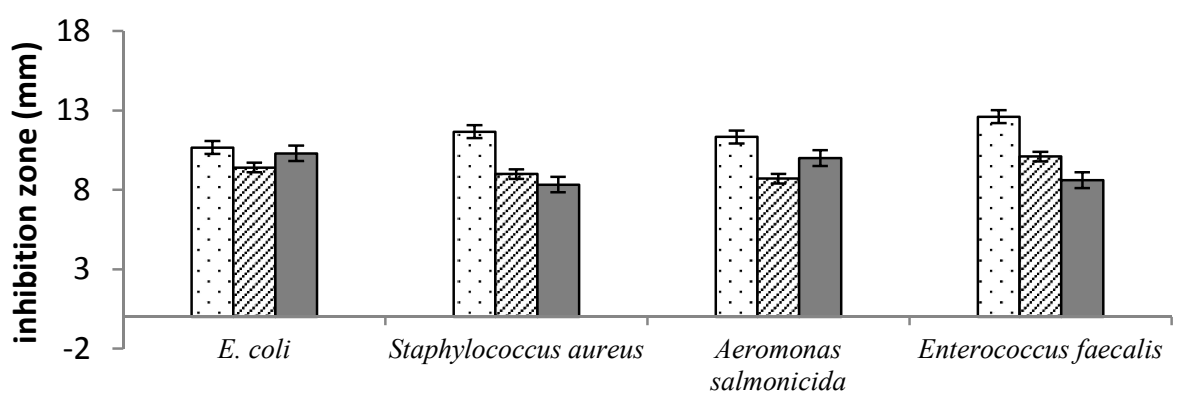

Pathogenic organisms

Fig. 1: Antimicrobial activity of LAB against coded test pathogenic organisms. 

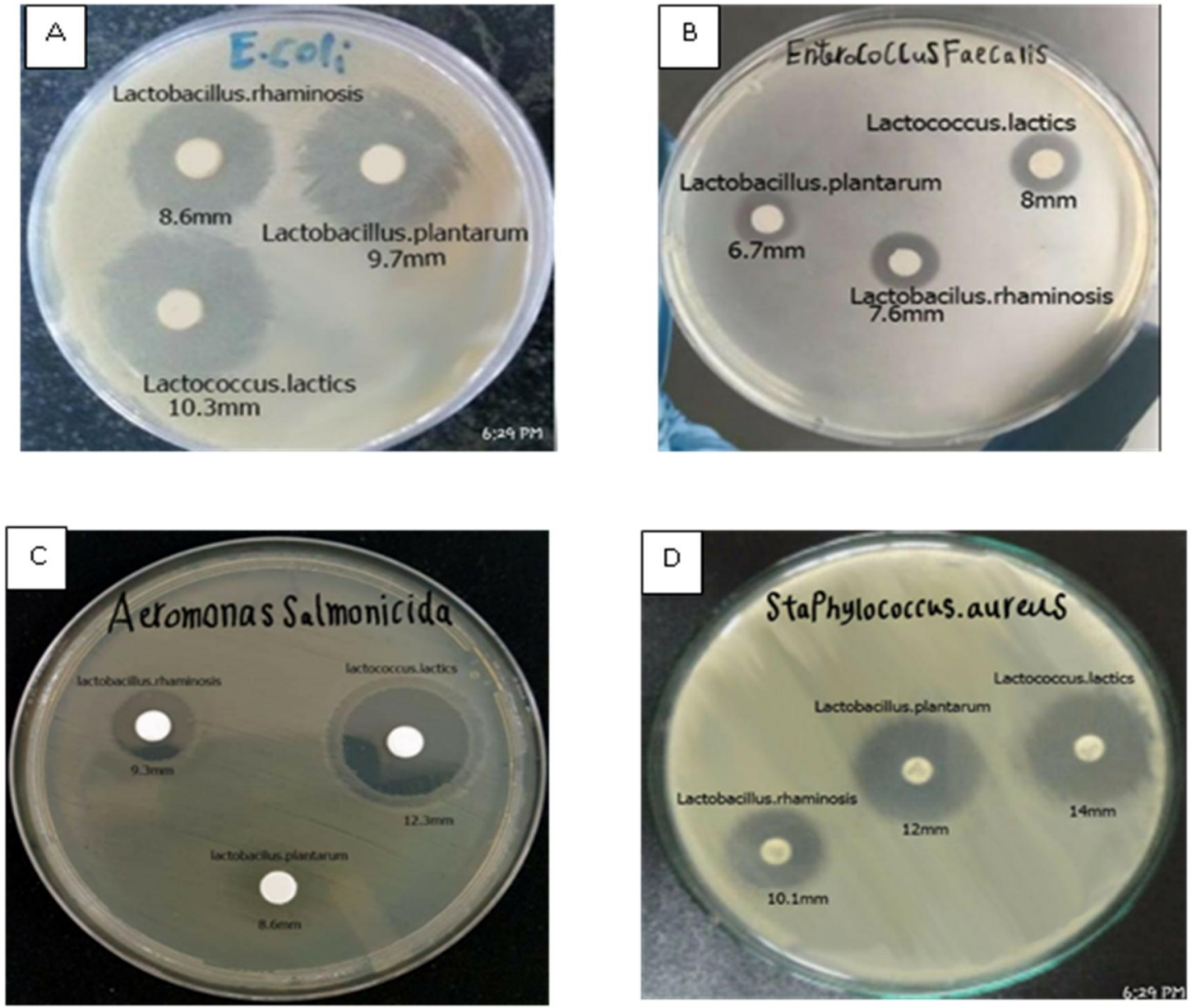

Plate 1: Antimicrobial activity of lactobacillus spp. against coded test food borne organisms represent LAB against E.coli; B, represent Lactococcus spp. against Enterococcus faecalis; C, represent LAB against Aeromonas salmonicida and D, represent lactobacillus spp against Staphylococcus aureus .

\subsection{Antibiotics susceptibility assay.}

The antibiotic susceptibility assay of lactic acid bacteria isolates (Lactococcus lactis ; L. rhamnosus and L. plantarum) was carried out using paper disk methods against some antibiotics including Chloramphenicol $(30 \mu \mathrm{g})$, Vancomycin $(30 \mu \mathrm{g})$, Tetracycline $(30 \mu \mathrm{g})$, Erythromycin $(15 \mu \mathrm{g})$, Ampicillin $(10 \mu \mathrm{g})$, Sulfamethoxazole $(25 \mu \mathrm{g})$, Streptomycin $(25 \mu \mathrm{g})$ and Penicillin $(10 \mu \mathrm{g})$ on Mueller Hinton agar plates which expressed as diameter of inhibition zone in $(\mathrm{mm})$.

Data recorded in table (4), reveal that Lactococcus lactis showed the highest antibiotic resistant against most of the antibiotics used, followed by L. plantarum and L. rhamnosus. Meanwhile, the isolates of Lactococcus lactis; L. rhamnosus and L. plantarum showed all sensitivity to Ampicillin (10 $\mu \mathrm{g})$ and sulfamethoxazole $(25 \mu \mathrm{g})$. In this respect, several investigations reveal that some lactic acid bacteria, such as lactobacilli are resistant to common antibiotics such as vancomycin and tetracycline, as it having probiotic activities and could be used as an adjunct to food and /or antibiotic therapy (Li et al., 2019).

Table 4: Antibiotic susceptibility assay of Lactococcus spp and lactobacillus spp.

\begin{tabular}{lcccc}
\hline Isolates & $\begin{array}{c}\text { Agents } \\
\text { Chloramphenicol } \\
(\mathbf{3 0} \boldsymbol{\mu g})\end{array}$ & $\begin{array}{c}\text { Vancomycin } \\
(\mathbf{3 0} \boldsymbol{\mu g})\end{array}$ & $\begin{array}{c}\text { Tetracycline } \\
(\mathbf{3 0} \boldsymbol{\mu g})\end{array}$ & $\begin{array}{c}\text { Erythromycin } \\
(\mathbf{1 5} \boldsymbol{\mu g})\end{array}$ \\
\hline Lactococcus lactis & $\mathrm{R}$ & $\mathrm{MS}$ & $\mathrm{R}$ & $\mathrm{R}$ \\
L. rhamnosus & $\mathrm{S}$ & $\mathrm{R}$ & $\mathrm{MS}$ & $\mathrm{S}$ \\
L. plantarum & $\mathrm{R}$ & $\mathrm{MS}$ & $\mathrm{MS}$ & $\mathrm{MS}$ \\
\hline
\end{tabular}


Table 4: Cont.

\begin{tabular}{lcccc}
\hline Agents & $\begin{array}{c}\text { Ampicillin } \\
(\mathbf{1 0} \boldsymbol{\mu g})\end{array}$ & $\begin{array}{c}\text { Sulfamethoxazole } \\
(\mathbf{2 5} \boldsymbol{\mu g})\end{array}$ & $\begin{array}{c}\text { Streptomycin } \\
(\mathbf{2 5} \boldsymbol{\mu g})\end{array}$ & $\begin{array}{c}\text { Penicillin } \\
(\mathbf{1 0} \boldsymbol{\mu g})\end{array}$ \\
\hline Lactococcus lactis & $\mathrm{S}$ & $\mathrm{S}$ & $\mathrm{R}$ & $\mathrm{R}$ \\
L. rhamnosus & $\mathrm{S}$ & $\mathrm{S}$ & $\mathrm{MS}$ & $\mathrm{R}$ \\
L. plantarum & $\mathrm{S}$ & $\mathrm{S}$ & $\mathrm{R}$ & $\mathrm{MS}$ \\
\hline
\end{tabular}

Where, S: Sensitive (zone diameter $\geq 17.5 \mathrm{~mm}$ ); MS: Moderately sensitive (zone diameter 12.5-17.4 mm); R: resistant (zone diameter $\leq 12.4 \mathrm{~mm}$ ).

\section{Conclusion}

In this study, three Lactococcus spp.and lactobacillus spp. strains were isolated, selected and identified from vended dairy products by biochemical and molecular identification methods. The three LAB isolates showed high ability to tolerate both of acid and bile salt. Lactococcus lactis showed the highest antibiotic resistant against most of the antibiotics and showed high antibacterial activity against four coded test organisms ; Escherichia coli ATCC 8739, Aeromonas salmonicida ATCC 9033, Staphylococcus aureus ATCC 29213 and Enterococcus faecalis NCTC 10413, that was followed by L. plantarum and L. rhamnosus, respectively. Finally, the results brought out in this study could be helpful for obtaining an eco-friendly LAB strains from vended dairy products, having potential probiotic activity.

\section{References}

Bell, V., J. Ferrão, L. Pimentel, M. Pintado, and T. Fernandes, 2018. One health, fermented foods, and gut microbiota. Foods, 7(12): 195.

Demirbaş, F., H. Ispirli, A.A. Kurnaz, M.T. Yilmaz, and E. Dertli, 2017. Antimicrobial and functional properties of lactic acid bacteria isolated from sourdoughs. LWT-Food Science and Technology, 79: 361-366.

Faghfoori, Z., B.P. Gargari, A. Saber, M. Seyyedi, and A.Y. Khosroushahi, 2017. The investigation of the diversity of Lactobacilli spp. and assessment some probiotic properties in traditional dairy products in East Azerbaijan province in Iran. Iranian Journal of Pharmaceutical Research: IJPR, 16(4): 1538.

Fijan, S., 2016. Antimicrobial effect of probiotics against common pathogens. In Tech, Venkateswera, $1-32$.

Fijan, S., D. Sulc, and A. Steyer, 2018. Study of the in vitro antagonistic activity of various single-strain and multi-strain probiotics against Escherichia coli. International journal of Environmental Research and Public Health, 15(7): 1539.

Guessas, B. and M. Kihal, 2004. Characterization of lactic acid bacteria isolated from Algerian arid zone raw goats' milk. African Journal of. Biotechnology, 3(6): 339-342.

Haghshenas, B., M. Haghshenas, Y. Nami, A.Y. Khosroushahi, N. Abdullah, A. Barzegari, and M.S. Hejazi, 2016. Probiotic assessment of Lactobacillus plantarum 15HN and Enterococcus mundtii 50H isolated from traditional dairies microbiota. Advanced Pharmaceutical Bulletin, 6 (1): 37.

Hawaz, E., 2014. Isolation and identification of probiotic lactic acid bacteria from curd and in vitro evaluation of its growth inhibition activities against pathogenic bacteria. African Journal of Microbiology Research, 8(13): 1419-1425.

Jarocki, P., M. Podleśny, M. Krawczyk, A. Glibowska, J. Pawelec, E. Komoń-Janczara, and Z. Targoński, 2018. Complete genome sequence of Lactobacillus rhamnosus Pen, a probiotic component of a medicine used in prevention of antibiotic-associated diarrhoea in children. Gut Pathogens, 10 (1): 1-6.

Khaneghah, A.M., K. Abhari, I. Eş, M.B. Soares, R.B. Oliveira, H. Hosseini, and C.S. Ranadheera, 2020. Interactions between probiotics and pathogenic microorganisms in hosts and foods: A review. Trends in Food Science \& Technology, 95: 205-218. 
Kolacek, S., I. Hojsak, R.B. Canani, A. Guarino, F. Indrio, B. Pot, and Z. Weizman, 2017. Commercial probiotic products: a call for improved quality control. a position paper by the ESPGHAN working group for probiotics and prebiotics. Journal of Pediatric Gastroenterology and Nutrition, 65(1): 117-124.

Lane, D.J., 1991. 16S/23S rRNA sequencing. In Nucleic Acid Techniques in Bacterial Systematics, John Wiley and Sons, New York, 115-175.

Li, Y., L. Li, S. Kromann, M. Chen, L. Shi, and H. Meng, 2019. Antibiotic resistance of Lactobacillus spp. and Streptococcus thermophilus isolated from Chinese fermented milk products. Foodborne Pathogens and Disease, 16(3): 221-228.

Liu, W., Q. Bao, M. Qing, X. Chen, T. Sun, M. Li, and H. Zhang, 2012. Isolation and identification of lactic acid bacteria from Tarag in Eastern Inner Mongolia of China by 16S rRNA sequences and DGGE analysis. Microbiological Research, 167(2): 110-115.

Miller, D.N., J.E. Bryant, E.L. Madsen, and W.C. Ghiorse, 1999. Evaluation and optimization of DNA extraction and purification procedures for soil and sediment samples. Applied and Environmental Microbiology., 65: 4715-4724.

Mulaw, G., and A. Tesfaye, 2017. Technology and microbiology of traditionally fermented food and beverage products of Ethiopia: a review. African Journal of Microbiology Research, 11(21): 825-844.

Mulaw, G., T. Sisay Tessema, D. Muleta, and A. Tesfaye, 2019. In vitro evaluation of probiotic properties of lactic acid bacteria isolated from some traditionally fermented Ethiopian food products. International Journal of Microbiology, 7179 514, 11 pages.

Ozteber, M. and G. Başbülbül, 2017. Antibiotic resistance patterns of lactic acid bacteria isolated from different fermented milk products of Turkish origin. Microbiology Research Journal International, 1-13.

Prete, R., S.L. Long, A.L. Gallardo, C.G. Gahan, A. Corsetti, and S.A. Joyce, 2020. Beneficial bile acid metabolism from Lactobacillus plantarum of food origin. Scientific Reports, 10 (1): 1-11.

Rondanelli, M., M.A. Faliva, S. Perna, A. Giacosa, G. Peroni, and A.M. Castellazzi, 2017. Using probiotics in clinical practice: Where are we now? A review of existing meta-analyses. Gut Microbes, 8 (6): 521-543.

Santacroce, L., I.A. Charitos, and L. Bottalico, 2019. A successful history: probiotics and their potential as antimicrobials. Expert Review of Anti-Infective Therapy, 17 (8): 635-645.

Schleifer, K.H. and J.A. Bell, 2009. Bergey's manual of systematic bacteriology. The Firmicutes. second edition ed. New York: Springer, 392.

Shokryazdan, P., M. Faseleh Jahromi, J.B. Liang, and Y.W. Ho, 2017. Probiotics: from isolation to application. Journal of the American College of Nutrition, 36 (8): 666-676.

Terpou, A., A. Papadaki, I.K. Lappa, V. Kachrimanidou, L.A. Bosnea, and N. Kopsahelis, 2019. Probiotics in food systems: Significance and emerging strategies towards improved viability and delivery of enhanced beneficial value. Nutrients, 11(7): 1591.

Toplaghaltsyan, A., I. Bazukyan, and A. Trchounian, 2017. The effects of different carbon sources on the antifungal activity by lactic acid bacteria. Current Microbiology, 74 (2): 168-174.

Vale, F.F., J.M. Vítor, and M. Oleastro, 2016. Probiotics as an Alternative Therapy for Helicobacter pylori-Associated Diseases. In Helicobacter pylori Research (pp. 543-574). Springer, Tokyo.

Vinderola, G., M. Gueimonde, C. Gomez-Gallego, L. Delfederico, and S. Salminen, 2017. Correlation between in vitro and in vivo assays in selection of probiotics from traditional species of bacteria. Trends in Food Science \& Technology, 68: 83-90.

Xiao, Y., J. Zhao, H. Zhang, Q. Zhai, and W. Chen, 2020. Mining Lactobacillus and Bifidobacterium for organisms with long-term gut colonization potential. Clinical Nutrition, 39(5): 1315-1323. 